Prepared for the U.S. Department of Energy

under Contract DE-AC05-76RL01830

\title{
Comparison of glass surfaces as a countertop material to existing surfaces
}

LA Turo

AE Winschell

September 2011

Pacific Northwest

NATIONAL LABORATORY

Proudly Operated by Battelle Since 1965 


\title{
DISCLAIMER
}

This report was prepared as an account of work sponsored by an agency of the United States Government. Neither the United States Government nor any agency thereof, nor Battelle Memorial Institute, nor any of their employees, makes any warranty, express or implied, or assumes any legal liability or responsibility for the accuracy, completeness, or usefulness of any information, apparatus, product, or process disclosed, or represents that its use would not infringe privately owned rights. Reference herein to any specific commercial product, process, or service by trade name, trademark, manufacturer, or otherwise does not necessarily constitute or imply its endorsement, recommendation, or favoring by the United States Government or any agency thereof, or Battelle Memorial Institute. The views and opinions of authors expressed herein do not necessarily state or reflect those of the United States Government or any agency thereof.

\author{
PACIFIC NORTHWEST NATIONAL LABORATORY \\ operated by \\ BATTELLE \\ for the \\ UNITED STATES DEPARTMENT OF ENERGY \\ under Contract DE-AC05-76RL01830
}

Printed in the United States of America
Available to DOE and DOE contractors from the Office of Scientific and Technical Information,
P.O. Box 62, Oak Ridge, TN 37831-0062;
ph: (865) 576-8401
fax: $(865)$ 576-5728
email: reports@adonis.osti.gov

\begin{abstract}
Available to the public from the National Technical Information Service, U.S. Department of Commerce, 5285 Port Royal Rd., Springfield, VA 22161 ph: (800) 553-6847 fax: $(703) 605-6900$ email: orders@ntis.fedworld.gov online ordering: http://www.ntis.gov/ordering.htm
\end{abstract}

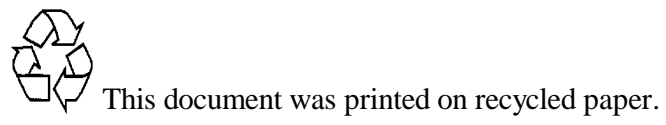




\section{Contents}

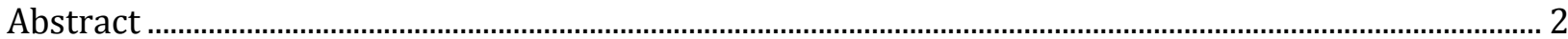

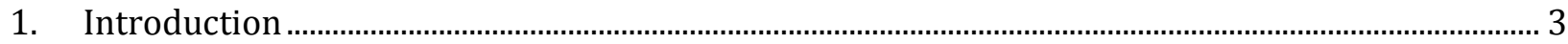

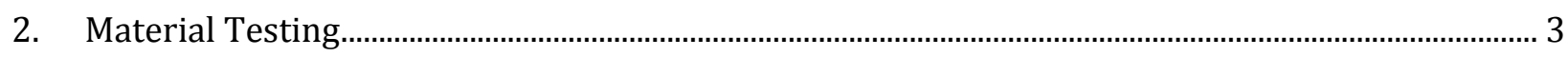

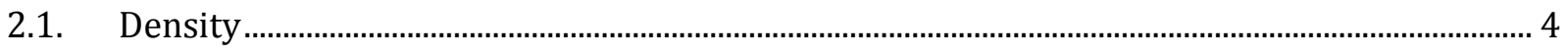

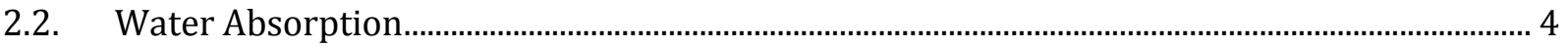

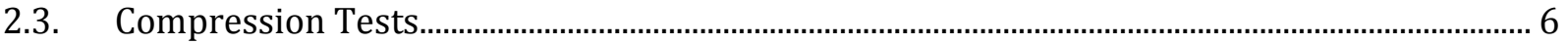

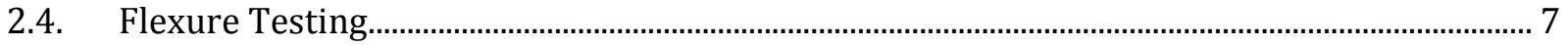

2.5. Thermal Shock Tests............................................................................................................................. 8

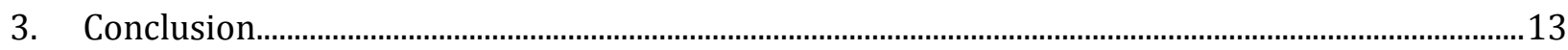

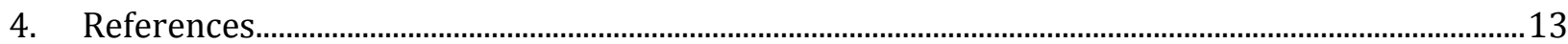

\section{Abstract}

This study compared three (3) glass surfaces by the company, Gleen Glass, to existing surfaces granite and marble. Results showed the glass surfaces have a lower density, lower water absorption, and are stronger in compressive and flexural tests as compared to granite and marble. Thermal shock tests revealed the glass failed when objects with a high thermal mass are placed directly on them, whereas marble and granite did not fracture under these conditions. 


\section{Introduction}

Gleen Glass, a small production glass company that creates countertops, was selected for the Technology Assistance Program through Pacific Northwest National Laboratory. Gleen Glass was seeking material property analysis comparing glass as a countertop material to current surfaces (i.e. marble, granite and engineered stone). With samples provided from Gleen Glass, testing was done on granite, marble, and 3 different glass surfaces ("Journey," "Pebble," and "Gleen").

Glass surfaces created by Gleen Glass are made from recycled industrial glass into countertops and sinks. There is not a lot of literature available on glass as a countertop material, but it has the potential to be a viable recycled material in commercial and residential locations. The glass surfaces are very attractive and can help buildings that install them qualify for LEED certifications. The glass surfaces were found to have a lower density, lower water absorption, and are stronger in compressive and flexural tests as compared to granite and marble. The glass surfaces failed in thermal shock tests when objects with a high thermal mass are placed directly on them, whereas marble and granite did not fracture under these conditions.

The glass surfaces with their current composition are not an ideal for a location where high thermal masses could be placed on them; as in a kitchen. However, they are an excellent option in bathrooms and commercial spaces due to their extremely low permeability to water and consistent visual design.

\section{Material Testing}

A series of material tests were completed to quantify the properties of glass surfaces to marble and granite. The three surfaces produced by Gleen Glass are; "Gleen," several sheets of glass layered with variations in opacity fused together; "Journey," a clear, colorless solid glass; and "Pebble," many circular discs are fused together in the kiln creating circular/ellipse opaque patterns in the glass matrix. The granite was a tan natural stone with an epoxied surface, and the marble was a polished white marble slab. 


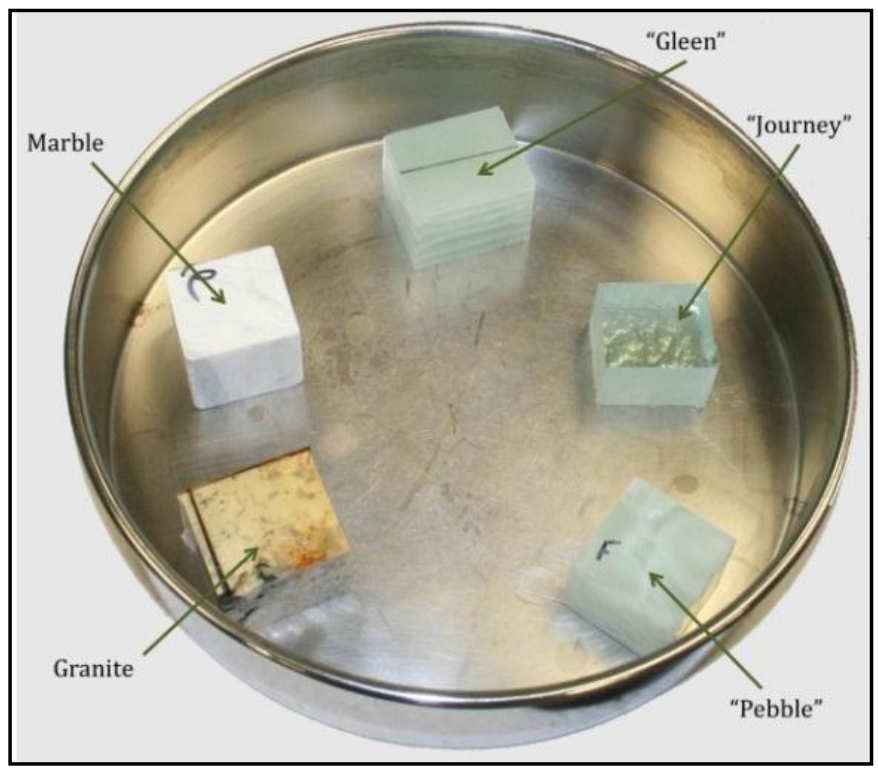

Figure 1: Countertop surfaces that were tested.

\subsection{Density}

Geometric density measurements were taken of all of the samples with consistent sample size. The glass surface, "Journey," had the lowest density, followed by "Gleen," "Pebble," granite, and marble. Results are shown in Figure 2.

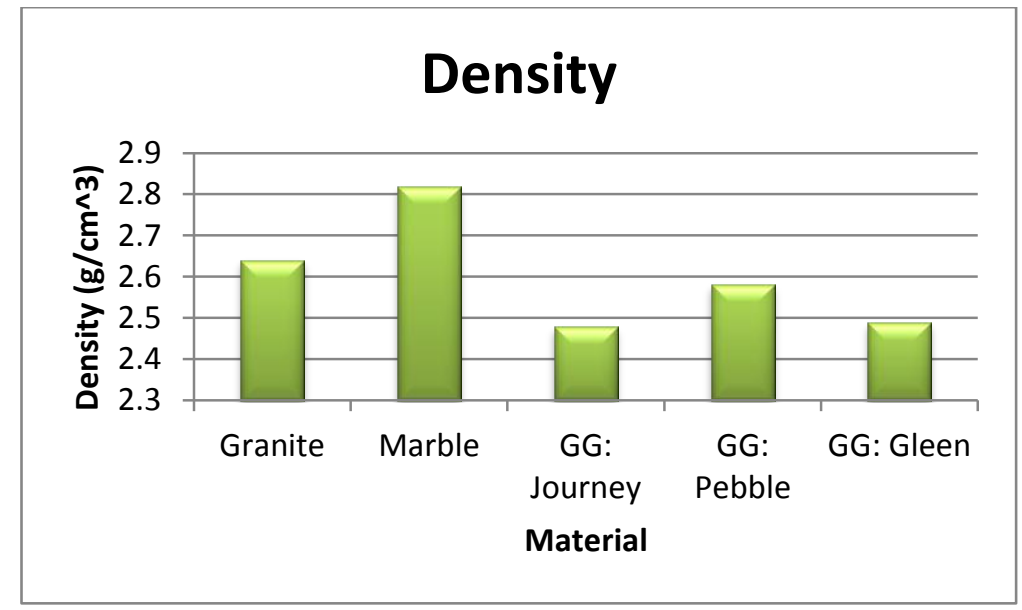

Figure 2: Density of countertop surface materials.

\subsection{Water Absorption}

Water absorption tests were done over two different time intervals. An initial 1-hour test was completed, as well as a 96-hour test to determine saturation absorption. The glass surfaces absorbed much less water than the granite and marble samples. Results are shown in Figure 3. 
The procedure for measuring water absorption was as follows:

- $\quad$ Samples were initially dried in an oven for 36 hours.

- When cooled, they were weighed to determine dry mass. Measurements were also taken at this time.

- Samples were boiled in deionized water (DIW) for approximately 1 hour.

- Samples placed in the boiled DIW and placed in desiccators under vacuum for approximately 2 hours.

- Cloth was dampened with fresh DIW. Samples removed from DIW and "dried" with dampened cloth.

- Weighed to determine wet mass.

Water absorption was determined by finding the amount of water absorbed divided by the initial weight and multiplied by 100, as in ASTM C 97. The weight percent of sample absorbed was also determined by the amount of water absorbed divided by the dry mass. Wet mass was taken 96 hours (after soaking in water) later to determine the saturated water absorption. The calculations to determine absorption were made in the same manner as the 1 hour samples.
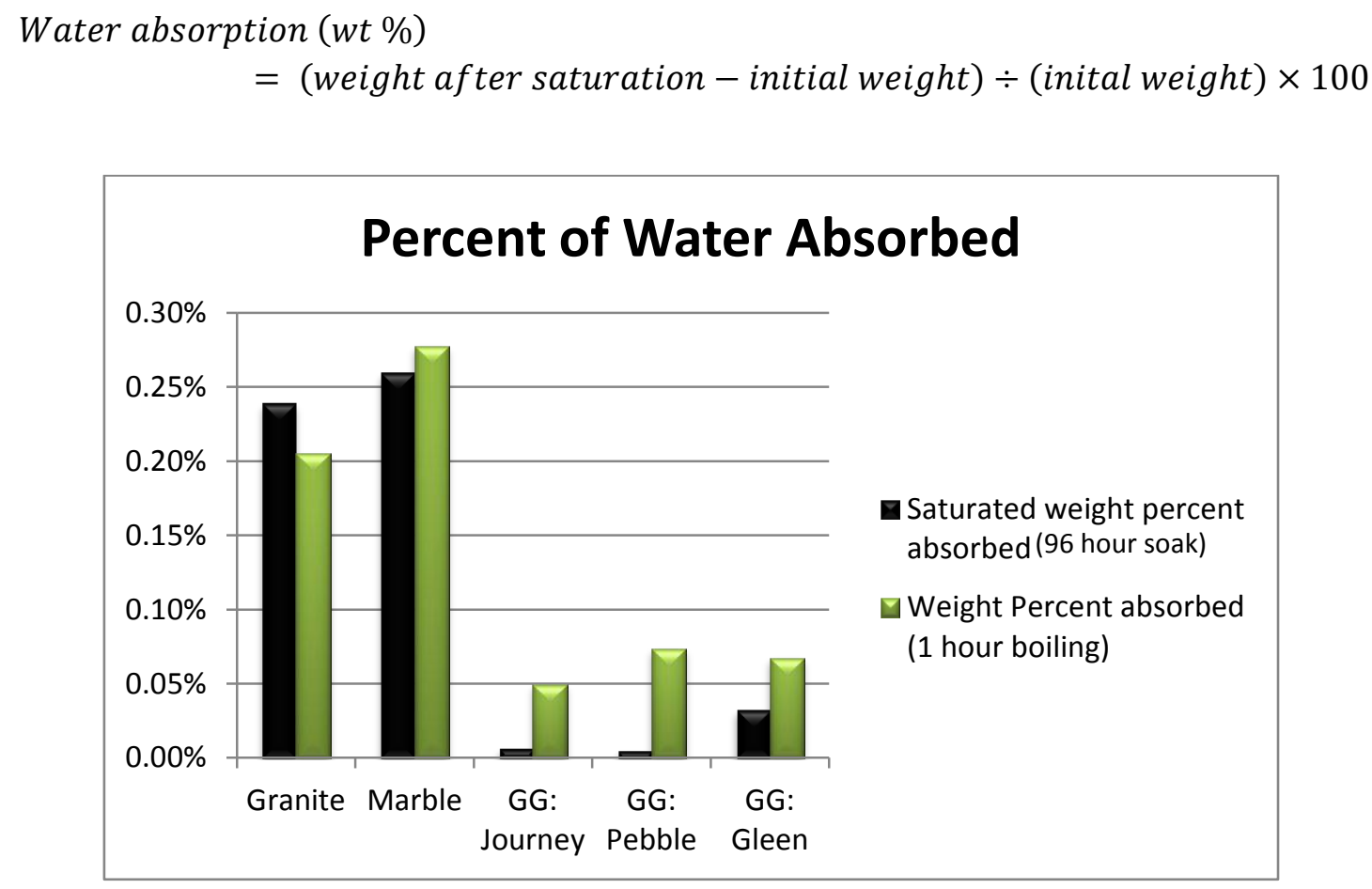

Figure 3. Water absorption of countertop surface materials

All materials tested did not have large absorption values, but the glass surfaces have a much higher resistance to water absorption than the current commercially available surfaces. Though there are 
fluctuations in absorption for the glass surfaces, absorption less than $0.1 \%$ are within experimental error and can be considered impermeable.

\subsection{Compression Tests}

Compression tests were performed on all 5 samples following the guidelines of ASTM C 170. Samples were tested twice due to limited amount of material. Results of the testing are shown in Figure 4.

The glass countertop materials were the strongest in compression and the Pebble glass failed at just under $90 \mathrm{ksi}$. Marble preformed the worst in the compression tests, failing at less than $5 \mathrm{ksi}$ in both tests. For purposes of compression on these materials; the glasses preform the best.

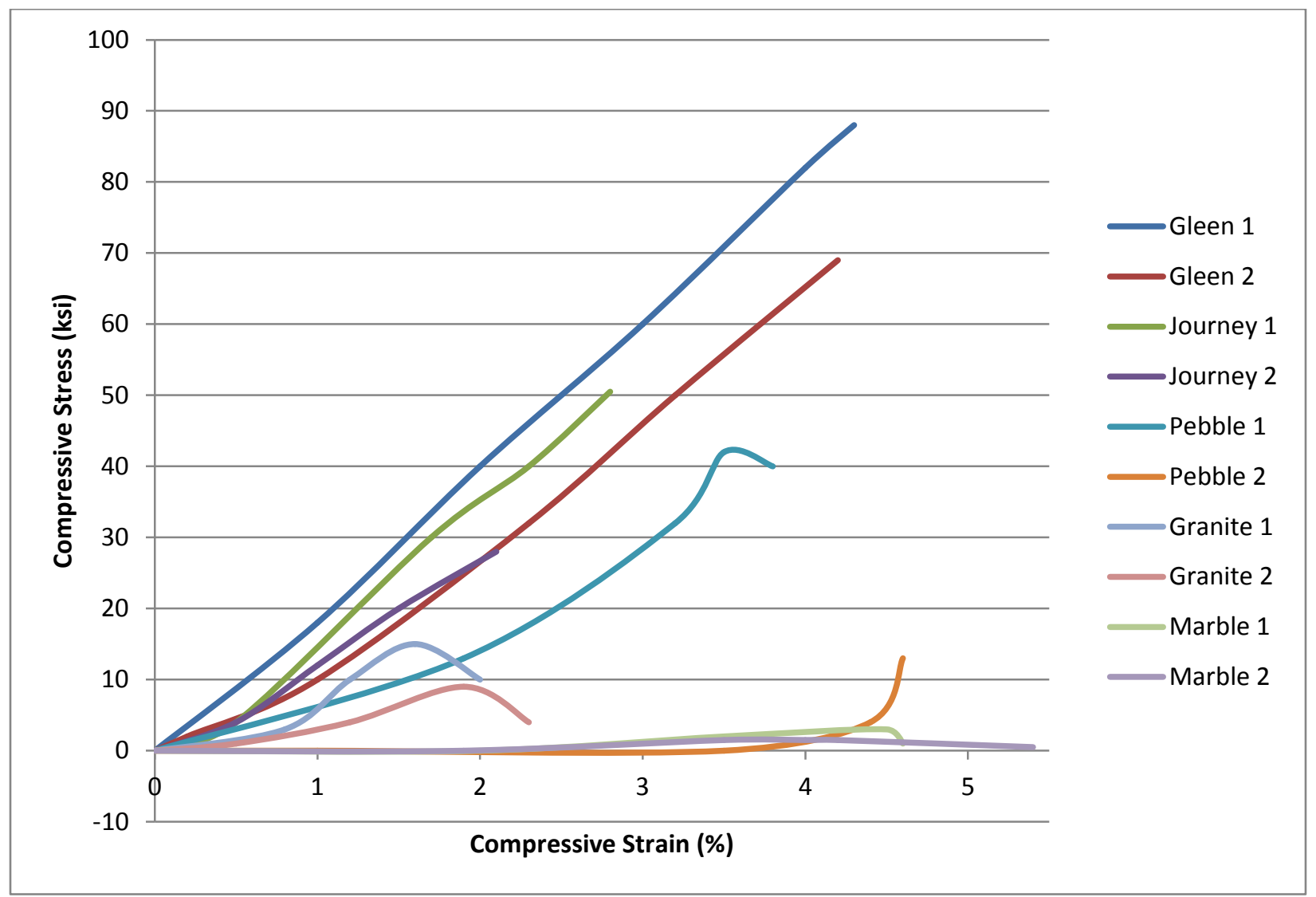

Figure 4: Compressive strength of countertop materials. 


\subsection{Flexure Testing}

Flexure testing via a 4-point bend test was performed on all of the samples following the guidelines of ASTM C 1161. Due to the limited amount of sample, the tests were done in duplicates only. The loading rate was at $0.2 \mathrm{~mm} /$ minute $(0.008 \mathrm{in} / \mathrm{min})$. Results of the testing were that the clear layered glass, "Journey" performed the best; breaking at 65 and 71 psi. The marble and granite samples broke considerably lower; multiple times below the detection limits. Figure 5 shows a setup of the flexural test apparatus, and Figure 6 shows the best represented strength and strain values from each set of samples.

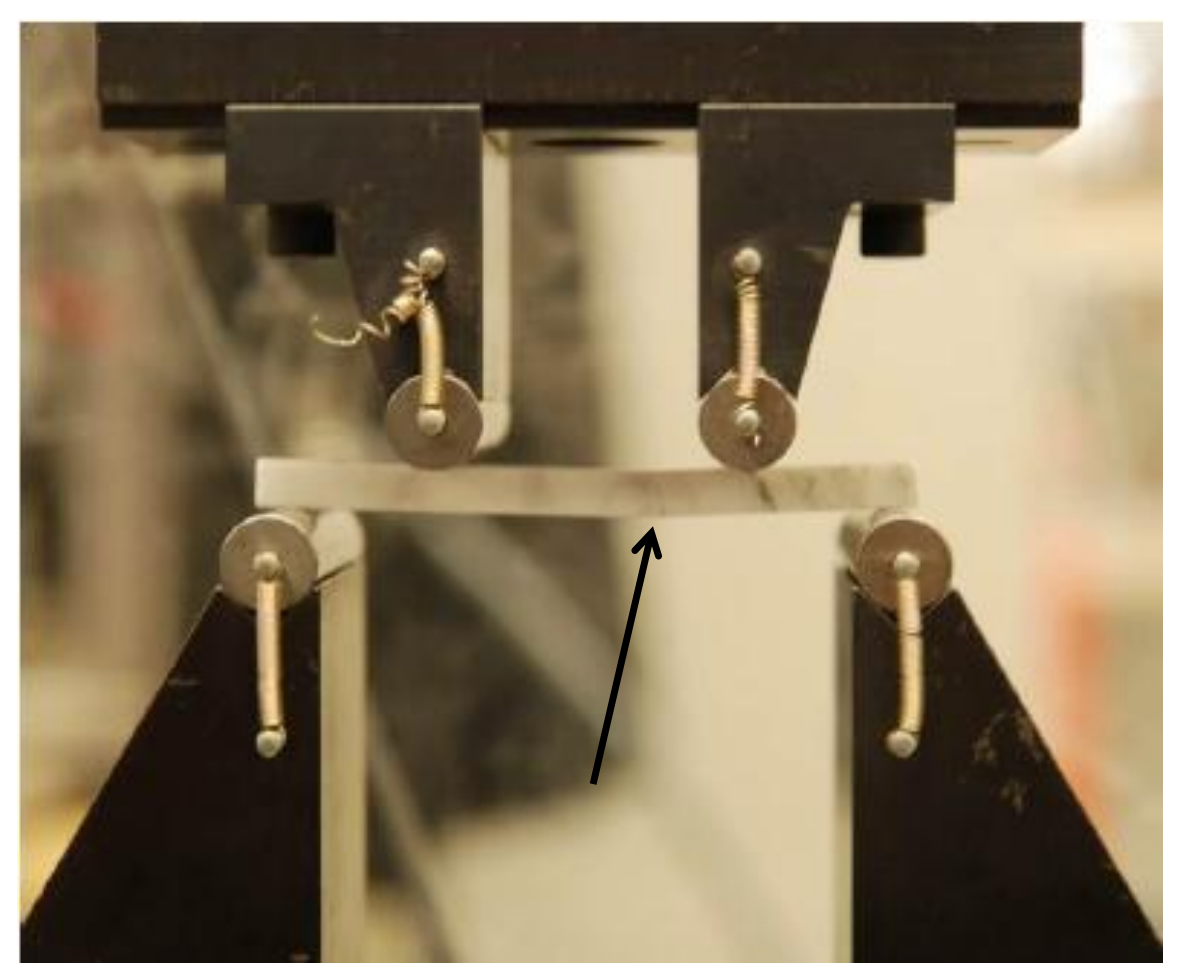

Figure 5: Set up of 4-point bend apparatus. Arrow shows detail of marble sample that broke below the detection limit. 
Gleen Glass: comparing glass surfaces to existing countertop materials

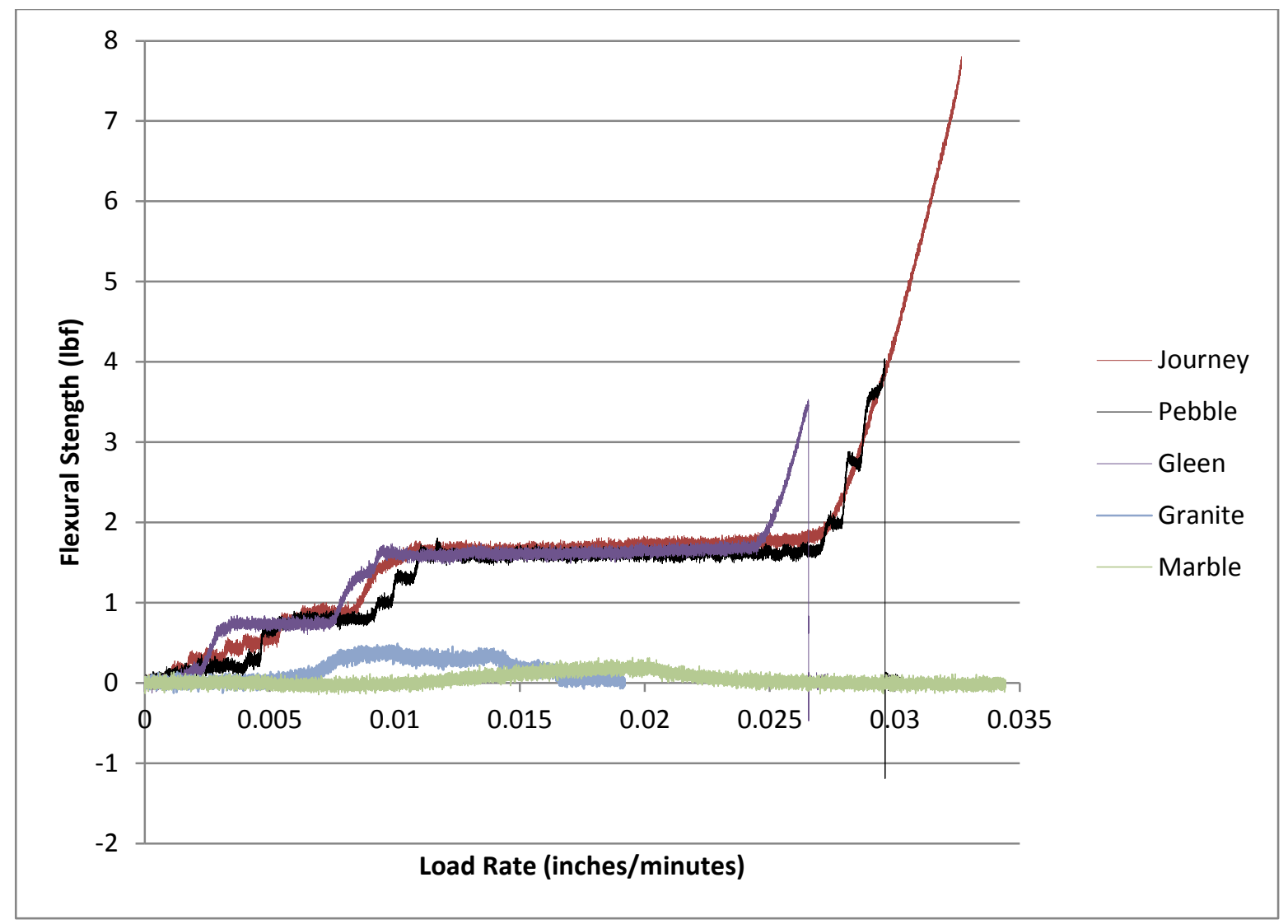

Figure 6: Flexural strength of countertop materials

\subsection{Thermal Shock Tests}

Thermal shock tests were performed in a manner that would closely represent a typical kitchen situation with very hot, high thermal mass, materials; as requested by Gleen Glass. Tests were done on small scale samples as well as larger bulk samples. The small samples were $2.54 \mathrm{~cm}^{3}$ (1 inch) cubes, and large sample dimensions are listed in Table 1. The procedure was as follows:

- Leave samples room temperature on an insulating material (such as cardboard)

- Heat a metal bar up to $176^{\circ} \mathrm{C}, 232^{\circ} \mathrm{C}, 287^{\circ} \mathrm{C}, 371^{\circ} \mathrm{C}$ (the equivalent of $350^{\circ} \mathrm{F}, 450^{\circ} \mathrm{F}, 550^{\circ} \mathrm{F}$, and $700^{\circ} \mathrm{F}$ ) in a furnace for 15 minutes

- Take the bar out with tongs and place on top of the countertop sample for 2 minutes

- Let the sample cool down for an hour between shock treatment

Results of the thermal shock tests are shown in Table 2 and Figures 7 through 22. 
Table 1: Large sample dimensions for thermal shock tests

\begin{tabular}{|c|c|c|c|c|c|}
\hline Sample Dimensions (cm) & Granite & Marble & GG: Gleen & GG: Journey & GG: Pebble \\
\hline Small & $2.5 \times 2.5 \times 2.5$ & $2.5 \times 2.5 \times 2.5$ & $2.5 \times 2.5 \times 2.5$ & $2.5 \times 2.5 \times 2.5$ & $2.5 \times 2.5 \times 2.5$ \\
\hline Large & $15.2 \times 3.7 \times 3.1$ & $12.1 \times 4.3 \times 2.9$ & $14.4 \times 5.6 \times 3.0$ & $12.6 \times 6.6 \times 2.3$ & $13.0 \times 7.0 \times 2.9$ \\
\hline
\end{tabular}

Table 2: Thermal Shock Values

\begin{tabular}{|c|c|c|c|c|c|c|c|c|}
\hline \multirow[b]{2}{*}{ Sample } & \multicolumn{2}{|c|}{$176^{\circ} \mathrm{C}\left(350^{\circ} \mathrm{F}\right)$} & \multicolumn{2}{|c|}{$232^{\circ} \mathrm{C}\left(450^{\circ} \mathrm{F}\right)$} & \multicolumn{2}{|c|}{$287^{\circ} \mathrm{C}\left(550^{\circ} \mathrm{F}\right)$} & \multicolumn{2}{|c|}{$371^{\circ} \mathrm{C}\left(700^{\circ} \mathrm{F}\right)$} \\
\hline & Small & Large & Small & Large & Small & Large & Small & Large \\
\hline Granite & $\begin{array}{l}\text { No signs of } \\
\text { cracking }\end{array}$ & $\begin{array}{l}\text { No signs of } \\
\text { cracking }\end{array}$ & $\begin{array}{l}\text { No signs of } \\
\text { cracking }\end{array}$ & $\begin{array}{l}\text { No signs of } \\
\text { cracking }\end{array}$ & $\begin{array}{l}\text { No signs of } \\
\text { cracking }\end{array}$ & $\begin{array}{l}\text { No signs of } \\
\text { cracking }\end{array}$ & $\begin{array}{l}\text { No signs of } \\
\text { cracking, but } \\
\text { burn marks } \\
\text { visible on top } \\
\text { surface }\end{array}$ & $\begin{array}{l}\text { No signs of } \\
\text { cracking }\end{array}$ \\
\hline Marble & $\begin{array}{l}\text { No signs of } \\
\text { cracking }\end{array}$ & $\begin{array}{l}\text { No signs of } \\
\text { cracking }\end{array}$ & $\begin{array}{l}\text { No signs of } \\
\text { cracking }\end{array}$ & $\begin{array}{l}\text { No signs of } \\
\text { cracking }\end{array}$ & $\begin{array}{l}\text { No signs of } \\
\text { cracking }\end{array}$ & $\begin{array}{l}\text { No signs of } \\
\text { cracking }\end{array}$ & $\begin{array}{l}\text { No signs of } \\
\text { cracking, but } \\
\text { burn marks } \\
\text { visible on top } \\
\text { surface }\end{array}$ & $\begin{array}{l}\text { No signs of } \\
\text { cracking }\end{array}$ \\
\hline GG: Gleen & $\begin{array}{l}\text { No signs of } \\
\text { cracking }\end{array}$ & $\begin{array}{l}\text { No signs of } \\
\text { cracking }\end{array}$ & $\begin{array}{l}\text { No signs of } \\
\text { cracking }\end{array}$ & $\begin{array}{l}\text { Crack at } 76 \\
\text { seconds } 2.0 \\
\mathrm{~cm} \text { in length }\end{array}$ & $\begin{array}{l}\text { No signs of } \\
\text { cracking }\end{array}$ & $\begin{array}{l}\text { Crack at } 40 \\
\text { seconds } 2.0 \\
\mathrm{~cm} \text { in length }\end{array}$ & $\begin{array}{l}\text { Large cracking } \\
\text { occurred ( } 71 \\
\text { seconds through } \\
\text { center of block) }\end{array}$ & $\begin{array}{c}\text { Crack at } 40 \\
\text { seconds } 5.8 \mathrm{~cm} \\
\text { and } 1.5 \mathrm{~cm} \text { in } \\
\text { length }\end{array}$ \\
\hline $\begin{array}{c}\text { GG: } \\
\text { Journey }\end{array}$ & $\begin{array}{l}\text { No signs of } \\
\text { cracking }\end{array}$ & $\begin{array}{l}\text { Crack after } \\
101 \text { seconds } \\
3.0 \mathrm{~cm} \text { in } \\
\text { length }\end{array}$ & $\begin{array}{l}\text { No signs of } \\
\text { cracking }\end{array}$ & $\begin{array}{l}\text { Crack at } 48 \\
\text { seconds } 2.3 \\
\mathrm{~cm} \text { in length }\end{array}$ & $\begin{array}{l}\text { No signs of } \\
\text { cracking }\end{array}$ & $\begin{array}{l}\text { Crack at } 45 \\
\text { seconds } 3.5 \\
\text { cm in length }\end{array}$ & $\begin{array}{l}\text { Small crack on } \\
\text { outer edge }\end{array}$ & $\begin{array}{c}\text { Crack at } 0 \\
\text { seconds } 2.8 \mathrm{~cm} \text {, } \\
5.5 \mathrm{~cm} \text {, and } 0.5 \\
\mathrm{~cm} \text { in length }\end{array}$ \\
\hline $\begin{array}{c}\text { GG: } \\
\text { Pebble }\end{array}$ & $\begin{array}{l}\text { No signs of } \\
\text { cracking }\end{array}$ & $\begin{array}{l}\text { No signs of } \\
\text { cracking }\end{array}$ & $\begin{array}{l}\text { No signs of } \\
\text { cracking }\end{array}$ & $\begin{array}{l}\text { Tiny surface } \\
\text { cracks at } 90 \\
\text { seconds }\end{array}$ & $\begin{array}{l}\text { No signs of } \\
\text { cracking }\end{array}$ & $\begin{array}{c}\text { No } \\
\text { additional } \\
\text { cracks }\end{array}$ & $\begin{array}{l}\text { No signs of } \\
\text { cracking }\end{array}$ & $\begin{array}{l}\text { Crack at } 59 \\
\text { seconds } 3.5 \mathrm{~cm} \\
\text { in length }\end{array}$ \\
\hline
\end{tabular}




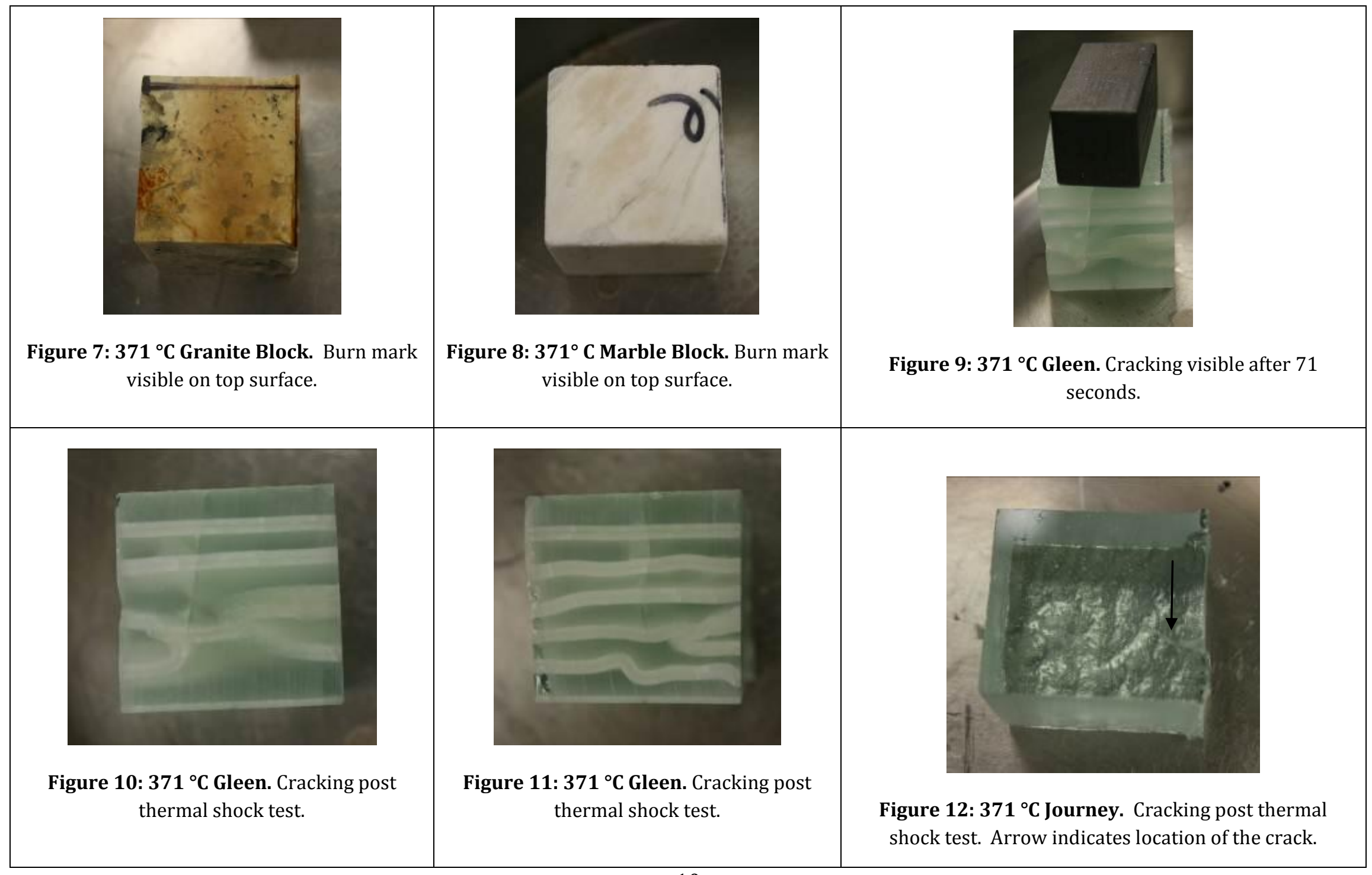




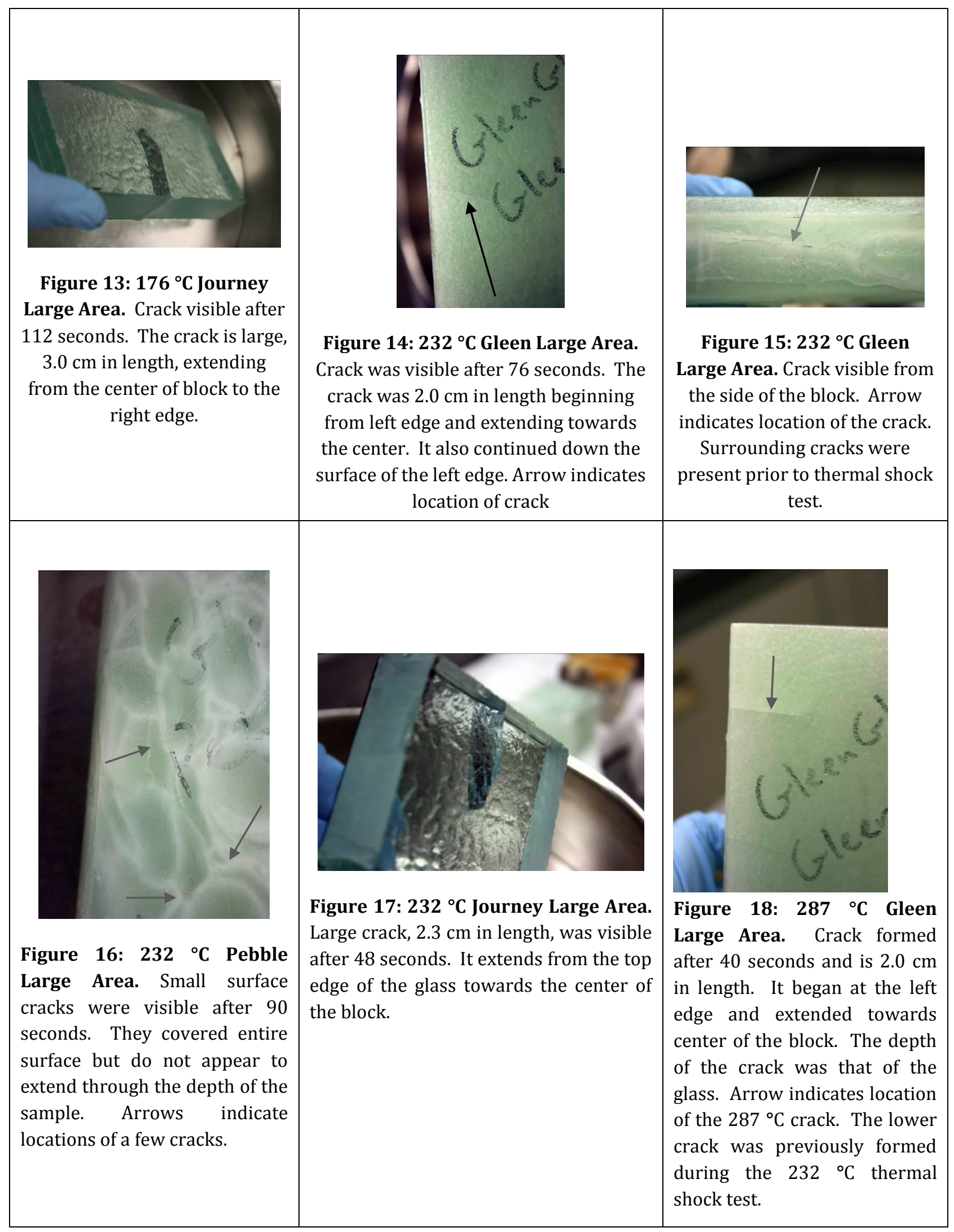




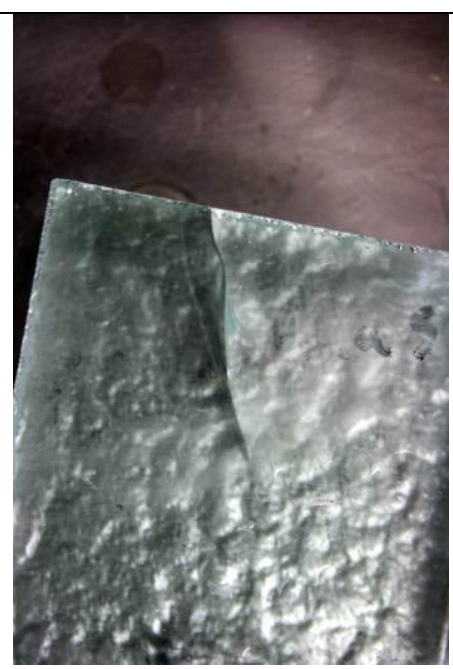

Figure 19: $287^{\circ} \mathrm{C}$ Journey Large Area. Crack was visible after 45 seconds. It is a large crack, $3.5 \mathrm{~cm}$ in length, extending from the bottom edge towards center of the block.

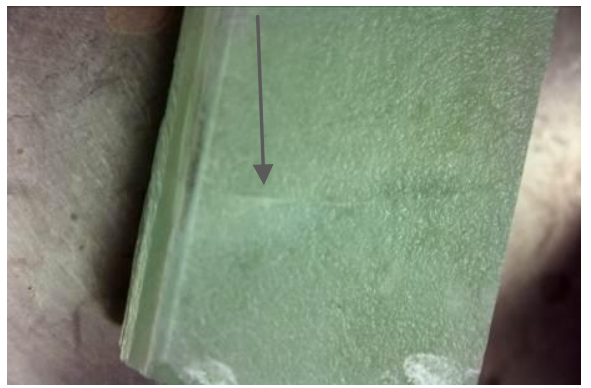

Figure 20: $371{ }^{\circ} \mathrm{C}$ Gleen Large Area. Crack formed after 40 seconds. It was large in size, $5.8 \mathrm{~cm}$ in length, extending across bottom portion of the sample. Arrow indicates location of the crack.
Figure 21: $371{ }^{\circ} \mathrm{C}$ Pebble Large Area. Large crack, $3.5 \mathrm{~cm}$ in length, formed after 59 seconds. It began at the top edge and extended towards the center of the block. Arrow indicates location of the crack.

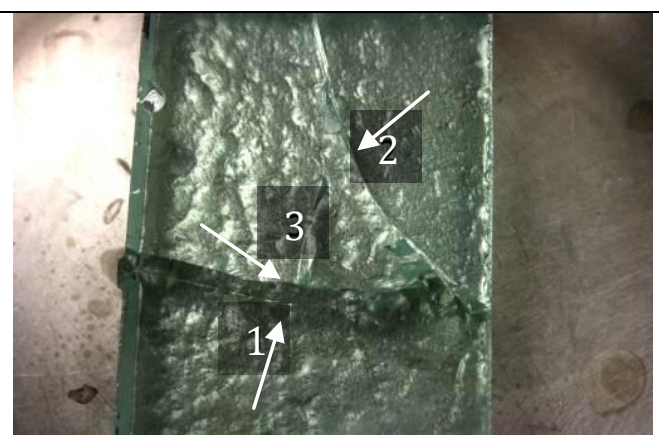

Figure 22: $371^{\circ} \mathrm{C}$ Journey Large Area. The cracks formed as soon as the steel bar was placed on glass surface. The cracks that were formed during the 176 ${ }^{\circ} \mathrm{C}$ ("1") and $232{ }^{\circ} \mathrm{C}$ ("2") grew and connected, as well as a new crack forming off of the $176^{\circ} \mathrm{C}$ crack ("3"). The cracks were $2.8 \mathrm{~cm}, 5.5 \mathrm{~cm}$, and $0.5 \mathrm{~cm}$ in length for arrows 1, 2 and 3 respectively. Arrows indicate location of the cracks and numbers correspond to the superscript numbers following the lengths. 


\section{Conclusion}

Glass materials are a viable option for countertops in a similar environment to the natural stone alternatives. The glass samples were much more sensitive to thermal shock, but had a much greater resistance to water absorption as well as surface bacterial growth (Sónia et al.) discovered from a brief literature search. The glass samples had a much higher capability for stress and strain loading compared to the natural stone alternatives in the flexure and compressive testing. The clear layered glass, "Journey," performed the best; breaking at 65 and 71 psi. The marble and granite samples broke considerably lower; multiple times below the detection limit. Since the glass surfaces are stronger than granite or marble in the flexural tests; they would be applicable to island overhangs, and potentially cantilevered edges with some under mount support.

The largest weakness of the glass countertops seems to be their sensitivity to thermal shock; the sample, "Journey," broke immediately upon high thermal mass being applied. All the cracks induced by thermal shock were substantial in terms of countertop strength after the crack was created, as well as aesthetically displeasing. The resistance to thermal shock on the glass samples could be improved upon with chemical formula modifications to the glass. Until the glass surfaces are compositionally modified, they are not an ideal for a location where high thermal masses could be placed on them; as in a kitchen. However, they are an excellent option in bathrooms and commercial spaces due to their flexural strength, extremely low permeability, and consistent visual design.

\section{References}

1. ASTM C97, 2009, "Standard Test Methods for Absorption and Bulk Specific Gravity of Dimension Stone,"ASTM International, West Conshohocken, PA, DOI: 10.1520/C0097_C0097M09, www.astm.org

2. ASTM C 170, 2009, "Standard Test Method for Compressive Strength of Dimension Stone," ASTM International, West Conshohocken, PA, DOI: 10.1520/C0170_C0170M-09, www.astm.org

3. ASTM Standard C 1161, 2008, "Flexural Strength of Advanced Ceramics at Ambient Temperature," ASTM International, West Conshohocken, PA, DOI: 10.1520/C116102CR08E01, www.astm.org

4. Silva, Sónia; Teixeira, Pilar; Oliveira, Rosário; Azeredo, Joana (2008). Adhesion to and Viability of Listeria monocytogenes on Food Contact Surfaces. Journal of Food Protection, 71 (7), 13791385. 